\title{
Harun Ar-Rasyid: Perkembangan ilmu pengetahuan pada masa Islam klasik (786-809 M)
}

\author{
Nuzulul Hidayati, Marsudi* \\ Universitas Negeri Malang, Jl. Semarang No. 5 Malang, Jawa Timur, Indonesia \\ *Penulis korespondensi, Surel: marsudi.fis@um.ac.id
}

Paper received: 01-04-2021; revised: 15-04-2021; accepted: 30-04-2021

\begin{abstract}
Most of us are very familiar with how the development of science in Europe, from the Dark Age to the Industrial Revolution, to forget how the development of science in the Islamic world. If Europe experienced a Dark Age, at that time, Islamic science was in its heyday. The triumphs did not escape the leaders at that time. In this article, the author will only focus on how the development of science during Harun ar-Rashid's time, including: 1) what is the background of Harun Ar-Rasyid, 2) what was the policy of Harun ar-Rashid's time, 3) how the science that developed in the era of Harun Ar-Rasyid.
\end{abstract}

Keywords: science; Islam; Harun Ar-Rasyid

\begin{abstract}
Abstrak
Sebagian besar dari kita sangat mengenal bagaimana perkembangan Ilmu pengetahuan di Eropa, dari masa Dark Age sampai Revolusi Industri hingga melupakan bagaimana perkembangan ilmu pengetahuan di dunia Islam. Jika Eropa mengalami masa Dark Age, pada masa itulah, Ilmu pengetahuan Islam sedang pada masa Kejayaannya. Kejayaan-kejayaan itu tidak luput dari para pemimpin pada masa itu. dalam artikel ini, penulis hanya akan memfokuskan bagaimana perkembangan ilmu pengetahuan pada masa Harun Ar-Rasyid, diantaranya: 1) bagaimana latar belakang Harun Ar-Rasyid, 2) bagaimana kebijakan pada masa Harun Ar-Rasyid, 3) bagaimana ilmu pengetahuan yang berkembang pada masa Harun Ar-Rasyid.
\end{abstract}

Kata kunci: ilmu pengetahuan; Islam; Harun Ar-Rasyid

\section{Pendahuluan}

Setelah tergulingnya kekhalifahan Ummayyah, Islam kembali bangkit dengan kekhalifahan yang baru. Kekhalifahan ini adalah kekhalifahan Abassiyah. Kekhalifahan berpusat di Kota Baghdad dan berkembang pesat yang juga menjadikan dunia Islam sebagai pusat pengetahuan. Nama Dinasti Abbasiyah ini diambil dari nama paman Nabi Muhammad SAW yang bernama al- Abbas ibn Abdul al-Munthalib ibn Hasyim (Samsudin \& Zuhri, 2018).

Kehalifahan ini kurang berminat melakukan penaklukan sebagaimana Dinasti Ummayah sebelumnya, tetapi lebih memfokuskan pada ilmu pengetahuan dan masalah dalam negeri (Samsudin \& Zuhri, 2018). Hal ini terlihat dari adanya upaya besar dalam menerjemahkan dan penyerapan ilmu pengetahuan dari peradaban lain, termasuk Mesir, Babilonia, Yunani, India, Cina, dan Persia.

Catatan sejarah menunjukkan bahwa Islam mencapai puncaknya pada masa Dinasti Abbasiyah, terutama di bawah kepemimpinan Khalifah Abu Ja'far al-Mansyur, Khalifah Harun Ar-Rasyid dan Abdullah al-Makmun (Samsudin \& Zuhri, 2018). Para khalifah ini sangat menyukai Ilmu pengetahuan. Hal ini dapat dilihat dari bagaimana mereka memelihara bukubuku dengan perbedaan agama dan ilmu pengetahuan umum, dan bagaimana mereka membayar penerjemah buku-buku di luar Arab. Selain itu, perkembangan ilmu pengetahuan 
yang pesat ini bisa dilihat dari Kota Baghad saat itu yang menjadi pusat ilmu pengetahuan dan juga kebudayaan.

Menurut Harun Nasution (dalam Mugiyono, 2013), ada banyak alasan mengapa periode ini disebut masa kejayaan ilmu pengetahuan, antara lain: Pertama, banyaknya ulama yang diangkat menjadi pegawai pemerintah untuk mendampingi khalifahan Abbasiyah, Kedua, pada masa Khalifah al-Makmun, Muktazilah diakui sebagai mazhab resmi negara. Mu'tazilah adalah paham yang menganjurkan kemerdekaan dan kebebasan berpikir kepada manusia. Ketiga, meningkatnya kemakmuran dan kesejahteraan umat Islam pada masa itu, Keempat, setelah wilayah Islam menguasai wilayah Romawi dan Persia, penduduk dari wilayah tesebut menjadi muslim yang taat, hingga terjadi asimilasi besar-besaran antara Arab dan `ajam (non-Arab). Kemudian mereka melahirkan para intelektual yang menjadi pelopor akulturasi budaya Islam dan lokal. Keturunan campuran ini memiliki keunggulan dalam kecerdasan akal, bentuk tubuh, keuletan dalam berusaha, berorganisasi, bersiasat, dan unggul dalam segala bidang kebudayaan.

Dalam makalah singkat ini penulis akan menfokuskan pembahasan masalah perkembangan ilmu pengetahuan pada masa kekhalifahan Harun Ar-Rasyid. Alasan penulis menuliskan perkembangan Ilmu Pengetahuan pada masa Harun Ar-Rasyid adalah dikarenakan pada masa beliaulah, awal mulai berkembangnya ilmu pengetahuan Islam. Nantinya, ilmu pengetahan ini akan dikembangkan dan dteruskan oleh khalifah-khalifah selanjutnya.

\section{Metode}

Dalam artikel ini kami menggunakan jenis penelitian yang berupa study kepustakaan (Library Research) yang merupakan suatu cara memperoleh data dengan membaca cermat dan pengambilan kesimpulan dari buku-buku di perpustakaan yang merupakan hasil dari para peneliti terdahulu, dalam penulisan artikel ilmiah ini juga meliputi langkah-langkah pengumpulan data, analisis dan interpretasi data dan dari sumber-sumber pustaka yang berhasil kami dapatkan dimana kami mengumpulkan bahan-bahan dari berbagai sumbersumber seperti buku, jurnal online, sesuai dengan tema yang kami bahas lalu kami interpretasikan.

\section{Hasil dan Pembahasan}

\subsection{Latar Belakang Khalifah Harun Ar-Rasyid}

Khalifah Harun Ar-Rasyid yang merupakan Khalifah ke-5 dinasti Abbasiyah ini memiliki nama asli Harun Ar-Rasyid Ibn al-Mahdi Ibn Abu Ja'far al-Mansyur, beliau ini lahir di kota Ray pada 17 Maret $145 \mathrm{H}$ atau $763 \mathrm{M}$. Harun Ar-Rasyid merupakan putra dari Khalifah Al-Mahdi, Khalifah ke-3 dinasti Abbasiyah (Ismiyati, 2015; Nasution, 2017). Harun Ar-Rasyid dikenal sebagai anak yang cerdas. Beliau mengampu pendidikan Islam dan pemerintahan sejak dini. Beliau berguru pada seseorang bernama Yahya bin Khalid. Dari pendidikan-pendidikan tersebut, Harun Ar-Rasyid tumbuh menjadi seorang yang terpelajar.

Pada usia remaja, ayah Harun Ar-Rasyid sudah menerjunkannya ke dunia pemerintahan. Beliau dipercaya oleh ayahnya untuk memimpin pasukan militer sebanyak dua kali, yang pertama yaitu untuk memimpin militer dalam penaklukkan Binzantium. Pada ekspedisi kedua Harun memimpin pasukannya menuju panta Borporus (Nasution, 2017). Di usia mudanya, 
Harun Ar-Rasyid telah dikenal memiliki wibawa. Hal ini terbukti dari tidakannya yang mampu menggerakkan 95 ribu pasukan beserta para pejabat tinggi dan veteran.

Sebelum dinobatkan sebagai Khalifah, Harun di perintahkan oleh ayahnya menjadi Gubernur di As-Syifah pada tahun 779 M dan di Maghrib pada tahun $780 \mathrm{M}$. Setelah 2 tahun menjabat sebagai Gubernur, Akhirnya beliau dinobatkan menjadi putra mahkota untuk menjadi Khalifah setelah sang kakak, Al-Hadi. Hingga pada 14 September 786, Harun Ar-Rasyid akhirnya menjadi Khalifah ke-5 Dinasti Abbasiyah.

Khalifah Harun Ar-Rasyid merupakan sosok yang peduli menjaga dan melestarikan syariat dan hukum-hukum Islam. Beliau juga seorang Khifah yang senang mendengarkan nasihat dari para ulama. Selain itu, Harun Ar-Rasyid juga merupakan sosok yang menggemari Ilmu pengetahuan. Beliau meneladani sikap dan kebijakan Khalifah ke-2 yaitu Ja'far AlManshur dan mengamalkannya, kecuali dalam hal pendistribusian harta benda.

Pada Masa pemerintahannya, banyak yang mengatakan bahwa pada saat itulah Islam sedang pada masa kejayaannya (Pramono, 2011). Ilmu pengetahuan berkembang pesat, rakyat makmur dan yang tidak boleh terlupakan adalah berjalannya syariat Islam di seluruh negeri. Karena itulah Harun Ar-Rasyid menjadi salah satu khalifah yang paling berpengaruh dalam perkembangan Islam.

\subsection{Kebijakan pada masa Harun Ar-Rasyid}

Khalifah Harun Ar-Rasyid dikenal sebagai tokoh yang kuat dalam segi kekuatan politik dan agama. Harun Ar-Rasyid memanfaatkan kekayaannya untuk kepentingan sosial. Kekayaannya dimanfaatkan untuk lembaga-lembaga pendidikan, lembaga-lembaga kesehatan, kebudayaan dan kesusastraan. Selain itu, Harun Ar-Rasyid juga mampu membuat perekonomian berkembang.perdagangan begitu lancar sehingga banyak yang mengkatakan bahwa Baghdad saat itu merupakan kota metropolitan yang menjadi pusat perdagangan terbesar dan teramai di dunia.

Kebijakan pada masa pemerintahan Harun Ar-Rasyid ini bisa dikatakan Kompleks. Hal ini dikarenakan kebijakan-kebijakan beliau mencakup berbagai bidang. Bidang-bidang tersebut diantaranya bidang kesehatan, bidang sosial, bidang Militer dan bidang Pendidikan.

Dalam bidang kesehatan, Harun Ar-Rasyid mendirikan banyak rumah sakit dan juga mendirikan lembaga pendidikan kedokteran dan farmasi. Di bidang Sosial, beliau mendirikan banyak pemandian umum. Di bidang militer, beliau menerapkan ilmu pengetahuan seperti fisika dan kimia dalam kemiliteran, membekali pasukan dengan peralatan yang mutakhir pada saat itu, melibatkan insinyur-insinyur dalam mengembangkan teknologi perang dan lain-lain. Dan yang terakhir dan terpenting dalam artikel ini adalah kebijakan di bidang keilmuan. Diantaranya adalah memuliakan guru dan ulama, mendirikan banyak perpustakaan, penerjemahan buku ilmu pengetahuan ke dalam bahasa Arab, penghargaan kepada siswa berprestasi, menjadikan masjid sebagai pusat pendidikan peran orang tua dalam pendidikan, menjadikan Al-qur'an sebagai pusat kurikulum dan mengutamakan ta'dib dalam pendidikan. Berikut adalah penjelasan dari kebijakan-kebijakan Harun Ar-Rasyid dalam bidang Ilmu Pengetahuan (Tadjuddin \& Maulana, 2018). 


\subsubsection{Memuliakan guru dan ulama}

Harun Ar-Rasyid merupakan seorang yang sangat menghargai ulama. Salah satu ulama yang di sukai oleh beliau adalah Imam Malik, saking senangnya, beliau pernah mengajak putranya yaitu Al-Amin dan Al-Ma'mun untuk mendengarkan Kitab Al-Muwartha' langsung dari Imam Malik. Khalifah Harun Ar-Rasyid juga sangat memuliakan guru, hal ini terlihat dari gaji guru pada saat itu yang berkisar dua ratus dinar setiap bulannya. Gaji tersebut diperoleh dari badan-badan wakaf yang ada pada saat itu.

\subsubsection{Mendirikan banyak perpustakan}

Perpustakaan beliau bangun guna memfasilitasi minat baca rakyatnya, bukan hanya yang ada di Baghdad, tapi juga di seluruh negeri. Perpustakaan juga memiliki peran penting, diantaranya menyimpan banyak ilmu pengetahuan, informasi dan dokumentasi. Pada masa Harun Ar-Rasyid, perpustakaan bukan hanya sebagai tempat baca, melainkan juga digunakan sebagai learning center dan resource center. Perpustakaan yang paling terkenal pada saat itu adalah Bait Al-Hikmah atau rumah kebijaksanaan. Perpustakaan ini adalah perpustakaan sekaligus lembaga pendidikan Islam yang pertama didirikan oleh Harun Ar-Rasyid di Ibukota Baghdad.

\subsubsection{Menerjemahkan buku-buku pengetahuan ke dalam bahasa Arab}

Gerakan penerjemahan ini adalah dampak asimilasi antara bangsa Arab dan bangsa nonArab yang telah mengalami perkembangan ilmu pengetahuan terlebih dahulu. Hal ini disebabkan karena banyaknya bangsa non-Arab yang masuk Islam pada dinasti Abbasiyah. Buku-buku yang diterjemahkan diantaranya buku-buku pengetahuan berbahasa Persia, Sansekerta, suriah dan Yunani. Dari hasil-hasil terjemahan tersebut, pengaruh yang kuat dalam bidang Filsafat banyak di dapat dari bangsa Yunani. Bidang kedokteran, Ilmu matematika dan astronomi mendapat banyak pengaruh dari India. Sedangkan bidang pemerintahan dan sastra banyak pengaruh dari Persia.

\subsubsection{Memberikan penghargaan kepada siswa berprestasi}

Khalifah Harun Ar-Rasyid adalah seorang yang menghargai anak-anak yang cerdas dan berprestsai, pada masanya, anak yang berprestasi akan mendapat kehormatan mengikuti parade. Dalam parade tersebut, si anak berprestasi akan menaiki unta dan diara ke seluruh kota dan juga dilempari buah Badam (kacang almond) sebagai bentuk sanjungan. Akan tetapi, hadiah-hadiah yang diberikan tidak boleh bersifat upah atau imbalan. Hal ini dikhawatirkan jika anak anak hanya berbuat baik dan belajar dengan giat karena mengharapkan imbalan.

\subsubsection{Menjadikan masjid sebagai pusat pendidikan}

Sejak masa Rasulullah SAW, masjid telah digunakan sebagai pusat pendidikan. Hal ini juga berlaku pada masa Khulaurrasyidin dan akhirnya tetap dilakukan pada masa pemerintahan Khalifah Harun Ar-Rasyid. Fungsi masjid juga sebagai tempat penyimpanan buku. Buku-buku tersebut diperoleh dari hadiah-hadiah yang diberikan kepada pengurus masjid. Oleh karena itulah, masjid pada masa itu menjadi tempat yang kaya akan buku-buku agama. 


\subsubsection{Melibatkan peran orangtua dalam pendidikan}

Hal ini berkaitan dengan perkataan ulama yang berbunyi, "anak adalah amanah bagi kedua orangtuanya" di mana peran orang tua sangat penting bagi perkembangan anaknya. Mendidik bukanlah pekerjaan yang mudah, mendidik dan mengajar adalah kebutuhan pokok dan kewajiban yang harus dipenuhi semua orang tua.

\subsubsection{Menjadikan Al-qur'an sebagai pusat kurikulum}

Pada sekolah dasar, kurikulum utamanya berpusat pada Al-Qur'an sebagai bacaan utama para siswa. Selain itu, siswa juga diajarkan baca-tulis dengan rujukan syair Arab tempo dulu. Pada masa itu, hampir seluruh kurikulum yang diterapkan mementingkan penghafalan Al-Qur'an.

\subsubsection{Mengutamakan ta'dib dalam pendidikan}

Ta'dib berasal dari kata addaba, yuaddibu dam ta'tib yang berarti adab atai mendidik manusia menjadi beradab. Dan secara Istilah, Ta'dib adalah istilah yang memiliki makna pendidikan yang didasarkan pada Al-Qur'an dan hadis Nabi Muhammad SAW. Menurut AlAttas, ta'dib adalah pendidikan yang penanaman adab kedalam seorang peserta didik. Tujuan dari pendidikan bukanlah untuk menciptakan pekerja yang baik, melainkan menciptakan manusia yang baik.

\subsection{Perkembangan Ilmu Pengetahuan pada Masa Islam Klasik}

Seperti yang telah disampaikan sebelumnya bahwa pada masa pemerintahan Harun ArRasyid lah, Islam mencapai puncak perkembangan peradaban, kebudayaan, dan ilmu pengetahuan. Hal ini tidak dapat dipungkiri karena Harun Ar-Rasyid sendiri sangan menyukai ilmu pengetahuan. Untuk berinteraksi dengan para Ilmuan dan juga ulama, Harun Ar-Rasyid menggunakan istananya sebagai pusat majelisnya (Agustini, 2016). Para ulama dan Ilmuan akan datang ke istana untuk berdiskusi dengan sang khalifah. Selain itu, Harun Ar-Rasyid juga senang mendatangi kediaman para ulama dan juga ilmuan yang mengadakan majelis Ilmu.

Istana pada masa pemerintahan beliau menjadi tempat berkumpulnya orang-orang berilmu baik ilmu itu balaghah, syair, sejarah, fiqih, kedokteran, musik dan berbagai ilmu lainnya. Para ilmuan yang berada di istana di berikan peghormatan dan kemuliaan. Para ilmuan-ilmuan berlomba-lomba dalam mengembangkan ilmu pengetahuan dan Harun ArRasyid sendiri tidak ragu untuk memberikan hadiah kepada ulama jika berhasil menghasilkan suatu karya (Agustini, 2016; Ismiyati, 2015). Maka tidak heran jika pada masa itu Ilmu pengetahuan di segala bidang sangatlah berkembang luas.

Berkembangnya Ilmu pengetahuan Islam yang menjadikan peradaban Islam berada di puncaknya ini disebabkan oleh beberapa faktor. Salah satunya adalah sistem pendidikan yang diterapkan menggunakan konsep multicultural. Nilai-nilai seperti toleransi, keterbukaan, kesederajatan, kebebasan keadilan, keragaman, demokrasi dikembangkan dalam sistem pendidikannya. Pendidik dengan visi dan misi budaya mendukung perkembangan ilmu pengetahuan yang cepat dan beradab (Agustini, 2016). 
Institusi yang ada pada masa pemerintahan Harun Ar-Rasyid juga memiliki muatan pendidikan yang mendukung, seperti memiliki materi, metode pembelajaran, dan pendidik yang dapat membantu pembelajaran dengan tepat. Dengan cara inilah lembaga pendidikan dapat menghasilkan lulusan berkualitas tinggi

Pada masa Harun Ar-Rasyid ini terdapat 4 tokoh pemuka agama yang sangat disegani. Keempat pemuka agama ini adalah tokoh yang melahirkan empat mazhab fiqh yang terus digunakan hingga saat ini (Agustini, 2016). Keempat tokoh tersebut di antaranya; Imam Abu Hanifah yang merupakan pendiri Mazhab Hanafi, Imam Maliki bin Anas yang merupakan seseorang yang banyak menulis hadis-hadis dan merupakan pendiri Mazhab Maliki, Muhammad bin Idris Ash-Syafi'I yang merupakan pendiri Mazhab Syafi'I dan Ahmad bin Hanbal yang merupakan pendiri Mazhab Hanbali.

\section{Simpulan}

Harun Ar-Rasyid hidup dan besar dengan dikelilingi keilmuan, oleh karena itulah beliau menjadi sangat mencintai Ilmu Pengetahuan. Selain itu, bukan hanya ahli dalam ilmu pemerintahan dan ilmu pengetahuan, beliau juga ahli dalam bidang kemiliteran. Sejak muda, meliau sudah disegani oleh para bawahanya dan tentunya di cintai oleh rakyatnya.

Kecintaannya terhadap ilmu pengetahuan membuatnya menciptakan kebijakankebijakan yang menunjang keilmuan. Pada saat beliau menjadi khalifah, beliau mendirikan Bait Al-Hikmah, yaitu perpustakaan yang menjadi pusat Ilmu pengetahuan dan kebudayaan. Pada masa beliau pula, dilakukan banyak sekali penerjemahan buku-buku ilmu pengetahuan dari bahasa asing ke bahasa Arab. Beliau tidak segan-segan memberika bayaran kepada sang penerjemah meskipun yang penerjemah itu bukan orang Arab ataupun Islam.

Bisa dikatakan perkembangan Ilmu pengetahuan pada masa beliau ini terjadi dikarenakan adanya kehidupan yang multikultural. Nilai-nilai seperti toleransi, keterbukaan, kesederajatan, kebebasan keadilan, keragaman, demokrasi dikembangkan dalam sistem pendidikannya. Sifat terbuka atau tidak kolot inilah yang membuat Islam pada masa itu terus berkembang.

\section{Daftar Rujukan}

Agustini, L. (2016). Peran Khalifah Harun Al Rasyid dalam Pengembangan Pendidikan Islam pada Masa Dinasti Abbasiyah (Doctoral dissertation, Fakultas Tarbiyah dan Ilmu Keguruan).

Ismiyati, N. (2015). Peranan Harun Al-Rasyid Dalam Kekhalifahan Abbasiyah Tahun 786-809.

Mugiyono, M. (2013). Perkembangan Pemikiran Dan Peradaban Islam Dalam Perspektif Sejarah. Jurnal Ilmu Agama: Mengkaji Doktrin, Pemikiran, dan Fenomena Agama, 14(1), 1-20.

Nasution, A. (2018). Perkembangan Ilmu Pengetahuan pada Periode Harun Al-Rasyid dan Al-Makmun. Jurnal Ilmiah Al-Hadi, 2(2), 395-402.

Martono, I. E., \& Pramono, M. F. (2011). Harmoni Nilai Agama Dan Nilai Ilmiah: Belajar Pengalaman Dunia Islam Dan Eropa. At-Ta'dib, 6(2).

Samsudin, M., \& Zuhri, M. (2018). Perkembangan Pendidikan Islam Pada Masa Harun Ar-Rasyid Dan AlMakmun. Alashriyyah, 4(1), 16-16.

Tadjuddin, N., \& Maulana, A. (2018). Kebijakan Pendidikan Khalifah Harun Ar-Rasyid. Al-Tadzkiyyah: Jurnal Pendidikan Islam, 9(2), 325-345. 